\title{
Luigi Orlandi
}

\section{A Lesser-Known Member of Bessarion's Milieu: The Scribe-Bishop Makarios}

\begin{abstract}
This paper aims to examine some Greek manuscripts produced in the mid-fifteenth century. Prosopographic, palaeographic and codicological pieces of evidence lead to the identification of the handwriting of the scribe-bishop Makarios.
\end{abstract}

Coordinated by Cardinal Bessarion, the intense campaign of transcription of manuscripts that led to the rescue of many works of ancient Greek literature has long been the subject of historical, philological, codicological, and, above all, palaeographic studies. Fundamental works about the activity of the copyists recruited by Bessarion between the 1440s and the 1470 s represented the basis for all later studies which, in turn, contributed towards progressively detailing the graphic and intellectual environment of that period. ${ }^{1}$

Within the framework of this fruitful field of research, recent studies are gradually bringing to light some lesser-known Byzantine émigrés in fifteenth century-Italy who performed, either intensely or marginally, the task of copying manuscripts in the cardinal's milieu. ${ }^{2}$ These are mostly neglected characters, who have been left in the shadows for different reasons.

More than once the impossibility of associating a name and a well-defined historical background with the manuscripts copied by scribes working for the Cardinal has been complained about, despite considerable discoveries; and this is the case, for instance, with some anonymous scribes who were grouped together a few decades ago by Dieter Harlfinger. Only in more recent times has it been possible to recognize historical personalities among them: consider the

1 The articles by Diller 1967 and Mioni 1976 have been pioneering in investigating this topic. Most of the copyists working for Bessarion are recorded among the specimina published in Harlfinger 1974.

2 Fundamental are the findings of Speranzi 2015, 2016, 2017, and 2018; see also Giacomelli and Speranzi 2019, Martínez Manzano 2013, Martinelli Tempesta 2013 and 2015, Orlandi 2015, 2019b and 2020b. 
case of the monk Gregorios (formerly Anonymus $K B)^{3}$ or that of Emmanuel of Constantinople (formerly Anonymus Ly). ${ }^{4}$

In contrast, historical personalities - well-known to contemporary literary and documentary sources and yet lacking a definite shape from a palaeographic point of view - had to wait many years before they were finally assigned a handwriting. The long path that led to the identification of the hand of the Moreote émigré Alexios Keladenos is striking. ${ }^{5}$ When he was still a boy, Alexios was greeted by Bessarion at the time of the Turkish conquest of the Peloponnese (which led to the surrender of Mystras in 1460), and he was initiated by the Cardinal himself into an undemanding ecclesiastical career in Italy. Much about him was known, save for his writing.

Eventually, under peculiar circumstances, it was only a change of perspective that made it possible to gather together manuscripts that appeared incongruent to each other. This is the case with Theodoros Gazes ${ }^{6}-$ whose writing bears two stylistic forms (calligraphic and cursive, the latter resembling Bessarion's own writing) - and with Athanasios Chalkeopulos, ${ }^{7}$ whose manuscripts have sometimes been unduly attributed to the Cardinal.

\section{2}

A similar case, briefly outlined in these pages, concerns a scribe who has remained anonymous until now, and yet had already been inscribed among Bessarion's collaborators for some time; this copyist contributed to the making of at least two manuscripts produced in the Cardinal's milieu: most of Proclus'

3 See Harlfinger 2011, 289 n. 13 and Martinelli Tempesta 2013, 126-130. A detailed biographical account of Gregorios (along with an update on his movements in Italy and his contacts to Italian humanists) is now provided in Giacomelli and Speranzi 2019.

4 See Orlandi 2019b.

5 For Keladenos, who has long been known as 'Anonymus $\delta$-кai Harlfinger' (= no. '2' of the list by Harlfinger 1971, 418) see Speranzi 2015 (with previous bibliography, necessary to follow the steps leading to the identification). Outside of the circle of Bessarion, we can refer to the case of Georgios Amirutzes; for a tentative identification of his writing see Orlandi 2019a.

6 For a study on the versatility of Gazes' writing refer to Speranzi 2012. This contribution provided the basis for a series of new findings: see Martinelli Tempesta 2013, 144; Orlandi 2015; Speranzi 2016, 83-87; Speranzi 2018, 195; Orlandi 2020a and 2020b.

7 See Speranzi 2018. 
Munich, BSB, Cod.graec. 547 (hereafter Monac. gr. 547) and a great number of folios within Aristotle's Vienna, ÖNB, phil. gr. 64 (hereafter Vind. phil. gr. 64). ${ }^{8}$

Within the manuscript Monac. gr. 547 (see Fig. 1), a small fifteenth-century paper codex, ${ }^{9}$ dating to $c .1455-1460$ as both internal and external evidence shows, ${ }^{10}$ Henri-Dominique Saffrey found autograph notes, written by the hand of Bessarion himself, ${ }^{11}$ including some accounting for the Cretan properties of the Latin Patriarchate of Constantinople: ${ }^{12}$ this is a first clue to a connection between the activity of the scribe and the Cardinal's milieu. Moreover, the Munich manuscript, which was still preserved in Venice in $1562,{ }^{13}$ was proved to have been part of Bessarion's collection, as its inclusion in the inventories of the Marciana studied by Lotte Labowsky clearly shows: in the catalogue 'B', compiled in 1474, it corresponds to item 529 Theologiae Platonis per Proculum. ${ }^{14}$ The results of philological investigations confirm in turn that the Munich manuscript originated in Bessarion's circle, ${ }^{15}$ as the text of Proclus' Theologia Platonica at fols $1^{\mathrm{r}}-301^{\mathrm{r}}$ is supposed to be a 'clean' transcription of that from another book owned by the Cardinal (that is Venice, Biblioteca Nazionale Marciana, gr. Z. 192). ${ }^{16}$ Then, in a codicological unit which is independent of the previous one, the transcription of the text of Proclus' Institutio theologica (fols $304^{\mathrm{r}}-354^{\mathrm{r}}$ ) - descending from the more ancient Marc. gr. Z. 512 (thirteenth century) ${ }^{17}$ - was started by a still-unidentified Byzantine hand (fols $304^{\mathrm{r}}-335^{\mathrm{v}}$ 1. 3) and was then completed by Bessarion himself (fols $335^{\mathrm{v}} 1.4-354^{\mathrm{r}}$ ). ${ }^{18}$

In the Vienna Aristotle, Phil. gr. 64, completed in Rome on March 25, 1457 ('in the second year of the papacy of Callistus III', as explicitly mentioned in the

8 Diktyon 71178. See Speranzi 2013, 126-128 and Speranzi 2018, 197-198.

9 Diktyon 44995. See a description by Paolo Eleuteri in Fiaccadori 1994, 419 no. 35 (with a specimen of the writing).

10 For further details regarding these chronological terms see here below.

11 Saffrey 1965.

12 These notes have been published and studied by Saffrey 1979.

13 See more below, n. 18.

14 Labowsky 1979, 219 and 487.

15 See Saffrey and Westerink 1968, CXXVII. See also Giacomelli 2020, 284-288.

16 Diktyon 69663. Details about the making of this 'allogenetic' manuscript - which is in fact a result of a project that took place over the sixth decade of the fifteenth century at different times and places (between Bologna and Rome), and involved more than one scribe working for Bessarion - are in Speranzi 2016, 63 n. 55.

17 Diktyon 69983. More information on the manuscript tradition of this work in Dodds 1963, XXXIII-XLI.

18 A copy of the text transmitted by the Monac. gr. 547 is found in Paris, BnF, gr. 1828 (Diktyon 51454), copied in Venice by Nicola Della Torre in the year 1562; see Dodds 1963, XXXVIII. 
subscription) ${ }^{19}$ the anonymous copyist of the Munich Proclus - collaborating in this case with Manuel Atrapes, Iohannes Rhosos, Hysaias of Cyprus (formerly known as 'Anonymus 25 Harlfinger') and the 'Anonymus 26 Harlfinger'20 - was responsible for fols $139^{\mathrm{r}}-216^{\mathrm{v}}$ (see Fig. 2). ${ }^{21}$ The Vienna manuscript, which belonged to Hysaias of Cyprus, provides therefore a first precise chronological and geographical frame of reference to date and locate the activity of this copyist: Rome, at the end of the 1450s.

\section{3}

On closer inspection, it is possible to associate the Greek hand of Monac. gr. 547 and Vind. phil. gr. 64 with a name. If we compare Figs 1-2 to Fig. 3, we will immediately notice the identity of the hands. The folio shown in Fig. 3 is from a volume of miscellaneous content, Arundel 528, currently in the British Library in London.22

As already indicated in the first volume of the Repertorium der griechischen Kopisten, ${ }^{23}$ the main copyist of Arundel 528 (fols $\left.9^{\mathrm{r}}-60^{\mathrm{v}}, 111^{\mathrm{r}}-181^{\mathrm{r}}, 185^{\mathrm{r}}-192^{\mathrm{v}}\right)^{24}$ signed his name in the London manuscript four times, presenting himself as Makarios, Bishop of Halicz (or Galyč), ${ }^{25}$ which is the eponymous city of the

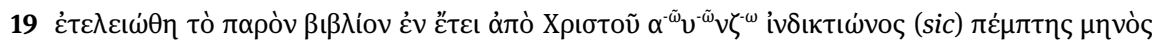

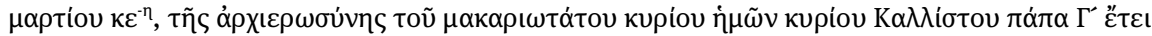
$\beta^{-\omega}[\ldots]$.

20 Harlfinger 1971, 419. See more about this scribe below, p. 757 and 758 n. 33.

21 A detailed description of the hands involved in the making of codex Vindobonensis (studied by Harlfinger 1971, 409, 419 and Rashed 2001, 31-32, 295-304) can be found in Speranzi 2013, 126-128. Speranzi was the first to connect the writing of fols $139^{\mathrm{r}}-216^{\mathrm{v}}$ with that of Monac. gr. 547. A full-page reproduction of this copyist's writing is already in Rashed 2001, Plate 46 (fol. 139'). For the critical edition of Theodoros Gazes' Solutiones (that is, solutions to problems dealing with Aristotelian physics) see Brockmann, Lorusso and Martinelli Tempesta 2017.

22 Dyktion 39279. A complete digitisation, including an analytical description of the content, is available at <bl.uk/manuscripts/>. From a philological point of view the manuscript was studied in Darrouzès 1961 and was used for the publication of the writings and letters of the monk Niketas Stethatos (for details on the manuscript transmission see Darrouzès 1961, 40-51). 23 See $R G K$ I 244.

24 Fols $1^{\mathrm{r}}-8^{\mathrm{v}}$ and $63^{\mathrm{r}}-110^{\mathrm{v}}$ are the work of other hands (see more below).

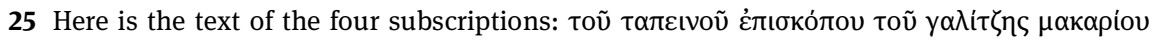

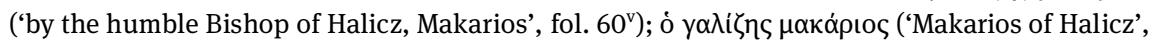

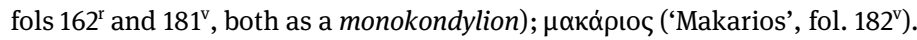


historical region of Galicia, incorporated during the fifteenth century into the Kingdom of Hungary and today under the jurisdiction of Ukraine.

Before moving on with further considerations about Makarios' activity, we shall examine other palaeographic aspects of the London manuscript, for two more hands appear in this book. While the one responsible for fols $1^{\mathrm{r}}-8^{\mathrm{v}}$ cannot be identified for now, the hand of fols $63^{\mathrm{r}}-110^{\mathrm{v}}$ is not at all unknown: we are dealing with a little-known Byzantine copyist, whose name is Philippos. The identity of this scribe was acknowledged some time ago by Rudolf S. Stefec. ${ }^{26}$ To the documentation collected by Stefec we can add evidence highlighted by other scholars. In a recent paper David Speranzi has attributed to an anonymous copyist - who is actually none other than Philippos - the following pieces: ${ }^{27}$ Vatican City, BAV, Vat. gr. 133 (Dyktion 66764); Milan, Biblioteca Ambrosiana, A 159 sup. (Dyktion 42245); part of Venice, Biblioteca Nazionale Marciana, gr. Z. 523 (Dyktion 69994) (fols $166^{\mathrm{r}}-186^{\mathrm{v}}, 187^{\mathrm{v}}-198^{\mathrm{r}}$ ), copied in collaboration with Emmanuel Zacharides, whose activity on the island of Crete is wellknown. ${ }^{28}$ In a detailed description of the Venice manuscript, ${ }^{29}$ Ciro Giacomelli pointed out that part of London, BL, Add. 58224 (Dyktion 39250) (fols $1^{\mathrm{r}}-65^{\mathrm{r}}$ ) is work of the same scribe; the collaboration with Zacharides in this manuscript, just as in Marc. gr. 523, is remarkable. Of Philippos' hand, in addition to Arundel 528, I have found three more witnesses, which I report here for the first time: the whole manuscript Paris, BnF, gr. 1969 (Dyktion 51596) (containing Plotinus' Enneads and dating to March 1467); Paris, Bnf, gr. 2141 (Dyktion 51770) (with

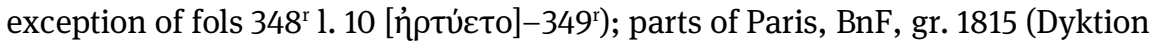
51441) (fols $71^{\mathrm{r}}-82^{\mathrm{v}}, 221^{\mathrm{r}}$ col. B-269 ${ }^{\mathrm{r}}, 267^{\mathrm{r}}-307^{\mathrm{v}} 1.20,325^{\mathrm{r}}-348^{\mathrm{v}}$ ). ${ }^{30}$

Besides the subscriptions by Makarios, Arundel 528, a small paper volume, also stands out due to the presence of some sections (fols $61^{\mathrm{r}}-62^{\mathrm{v}}, 183^{\mathrm{r}}-184^{\mathrm{v}}$ ) containing religious writings in mixed ecclesiastical Slavonic, Bulgarian and Serbian. In his surveys of manuscripts in Cyrillic alphabet kept in English and Irish collections, ${ }^{31}$ Ralph Cleminson already pointed out that Arundel 528 shows some similarities in language, writing and content with Arundel 527, another Greek codex (with musical writings) containing short Slavonic texts (fols $129^{\mathrm{v}}-131^{\mathrm{v}}$ ). ${ }^{32}$ It will not

26 See Stefec 2013, 308-310.

27 See Speranzi 2018, 214.

28 See $R G K$ I 114 = II 146 = III 189.

29 Available online at <cagb-db.bbwa.de $>$.

30 In a forthcoming study I shall present further insights into Philippos' activity as a scribe.

31 Cleminson 1988, 144-147.

32 A full digitisation and a detailed description of this manuscript is available at <bl.uk/ manuscripts/> as well. 
come as a surprise to find here, too, though only on the two folios $\left(5^{\mathrm{v}}-6^{\mathrm{r}}\right)$, the hand of Makarios, which had so far gone unnoticed (see Fig. 4). ${ }^{33}$

With the group of the four manuscripts entirely or partially written by Makarios it is possible to associate a further witness, Paris, BnF, gr. 1312 (Dyktion 50921; see Fig. 5). This small-sized paper manuscript, which is entirely written by Makarios' hand, contains an anonymous collection of 137 Capita moralia et theologica, to which a long index covering almost the whole first two quires (fols $1^{\mathrm{r}}-15^{\mathrm{r}}, 1.5$ ) is premised. In order to support the arguments addressed by these Capita, statements have been extracted from various types of texts: religious, liturgical, patristic, juridical, council acts. ${ }^{34}$ Copied in the monastery of St John the Prodrome-Petra, Par. gr. 1312 still preserves its original Byzantine binding. This kind of binding has been studied by a specialist such as Dominique Grosdidier de Matons, who called it 'couture provisoire par surfilage'. ${ }^{35}$ According to these elements, the Paris manuscript should therefore be considered a product of Makarios' scribal activity in the Byzantine East, which had remained in the shadows until now.

The Greek handwriting of Makarios, as it appears from the examination of the collected material (see Figs 1-5), is characterized first of all by a significant inclination of the axis to the right; generally speaking, it appears accurate and confident, not without a certain tendency to a calligraphic style. It is possible to give an account of some of its peculiar features (see Table 1): delta (1) is provided with a hook at its upper extremity and is mainly capital shaped; zeta, when tied with the previous letter (2), is traced in a peculiar way by means of the sequence of two left-handed loops; rho (3), as well as tau, ordinarily ties at the bottom with the following letter; peculiar is the sigma in ligature with the circumflex accent (4), produced by the upward extension of the horizontal stroke of the letter; very showy and characteristic is, finally, a flourish on the lower margin in the shaping of the abbreviation for the word kai (5), when it occurs within the text on the last line of the written area. ${ }^{36}$

33 Fols $1^{\mathrm{r}}-5^{\mathrm{r}}$ and $100^{\mathrm{v}}-116^{\mathrm{r}}$ are the work of different hands. On the name and the activity of the main scribe (see, for instance, fols $11^{\mathrm{r}}-100^{\mathrm{r}}$, containing musical works, $\dot{\alpha} v \alpha \gamma \rho \alpha \mu \mu \alpha \tau$ t $\sigma \mu \mathrm{o}$ and $\tau \rho о \pi \alpha ́ \rho(\alpha)$, whom I here identify as the so-called 'Anonymus 26 Harlfinger', who worked for Bessarion too, I shall give further insights in a forthcoming paper.

34 In the first chapter, for instance, which addresses the question of obedience to the monarch as the guarantor of divine order on earth, there are excerpts from St Peter and St Paul's sayings, a short passage Пєрi ü $\beta \varepsilon \omega \nu$ from the Synopsis basilicorum and, at the end, a few lines from the liturgy of St Basil.

35 See Grosdidier de Matons 2008.

36 See also Figs 2, 3 and 5. 
Table 1: The handwriting of Makarios of Halicz (details)

Vind.
phil. gr. 64
(in ligature)
Monac.
gr. 547
(in ligature)
Arundel 527
Arundel 528
gar. 1312

\section{4}

Having completed these first palaeographic surveys concerning the five manuscripts which are witnesses to the activity of Makarios as a copyist, it is possible to proceed further to some biographical remarks.

The personality of Makarios is not unknown in the studies of Byzantine prosopography, as an entry in the Prosopographisches Lexikon der Palaiologenzeit (PLP 16192) was dedicated to him. A member of the clergy and of Serbian origin, Makarios, before becoming bishop, had been a monk of the Basilian monastery 
of St Cyprian in Constantinople. His appointment as bishop of Halicz took place in Rome on January 16, 1458 on the initiative of Pope Callistus III. ${ }^{37}$ This historical event matches perfectly in terms of chronology with what we already knew about the activity of Makarios; that is his participation in the making of the Vienna manuscript Phil. gr. 64, which was completed in Rome in 1457 in cooperation with other scribes working for Bessarion.

In the frame of a structural reorganisation of the Byzantine-Slavic metropolis, the aim of the Roman Curia in those years was to gain jurisdiction over people following the Eastern rite and living in the Kingdom of Hungary (which also included the region of Halicz) by appointing a Byzantine-Slavic orthodox bishop who was not at odds with the stance of the Council of Ferrara-Florence (14371439); a project strongly contested by the Hungarian bishops and Latin clergy, who had never even officially signed the definitive document of the Union in 1439. Cardinal Isidoros, who had signed the Council Acts as Metropolitan of Kiev and All Russia, was at that time pontifical legate for those regions but not for the lands of Hungary, whose rulers were continuously quarrelling with the popes of Rome due to the long-standing issue of the direct nomination of the bishops. ${ }^{38}$

Makarios seems to have distinguished himself in the eyes of Callistus III for his many qualities (religionis zelus, litterarum scientia, vite mundicia, honestas, morum spiritualium prudencia, and temporalium circumspetio). ${ }^{39}$ Given his intimacy with Cardinal Bessarion, Makarios could have been appointed bishop of Halicz through the intercession of the Cardinal himself (and of the former Metropolitan Isidoros of Kiev). He certainly maintained his office, despite opposition from the Latin Hungarian clergy, at least until some time after 1466, when he was confirmed by Pope Paul II. ${ }^{40}$ From this date on, there is no more evidence about the activity of this scribe-bishop.

37 The text of the letter granting Makarios the nomination as bishop is published in Prochaska 1923, 64-65.

38 For a reconstruction of the story see Hofmann 1946, 227-229 and, more recently, Adam 2008. An updated biographical account of Isidoros is found in Philippides and Hanak 2018. Makarios' predecessor in Halicz was another orthodox monk, a certain Matthaios (remaining in office for the years 1440-1458): see Adam 2008, 333-336.

39 See Prochaska 1923, 65.

40 See Adam 2008, 336-337; the text of the letter of Paul II to the Archbishops of Esztergom and Kalocsa confirming the authority and jurisdiction of Makarios can be found in Bunea 1904, 301-303. 
We will now try to take a further step in the shaping of the biographical and intellectual profile of Makarios of Halicz by examining the possibility of a shared identity with other contemporary namesake individuals.

The first figure to be taken into consideration is the half-unknown Makarios of Serres, who has also been recorded, under different entry numbers, in the prosopographic and palaeographic repertoires (PLP 16274; RGK III 402). The only information referring to this Makarios, otherwise unknown to the documentary sources of the time, comes from a short letter handed down by the manuscript Vatican City, BAV, Vat. gr. 1858 (Dyktion 68487) (fols $2^{\mathrm{v}}-3^{\mathrm{r}}$ ). The text of the epistle dates to the year $<1447>$ and is in all likelihood autograph, as some editorial corrections show..$^{41}$ Makarios, who presents himself in the first lines as the Metropolitan of Serres, addresses a request to an orthodox monk and hegumenos, named Isidoros: ${ }^{42}$ the purpose of the letter is to obtain permission to return to the monastery he belonged to - unfortunately it is not specified which one - provided that Makarios refuses the unionist positions of the Council of Ferrara-Florence which he had supported for some time. ${ }^{43}$

The handwriting of Makarios of Serres as it appears in the Vatican manuscript (fols $2^{\mathrm{v}}-3^{r}$ ) is marked by an extremely cursive style, which perfectly fits the 'personal' character of the document, but which does not easily match with the pieces of evidence previously ascribed to the hand of Makarios of Halicz, as they were are all quite calligraphic. Because of this formal distance, the two writings would therefore seem, at first sight, completely foreign to each other. Nevertheless, as shown by some palaeographic features (listed below in Table 2), the main characteristics of the writing of Makarios of Serres overlap with those of the Greek hand of the Bishop of Halicz, some of which have

41 See Mercati 1926, 36, who pointed out the autography and the dating of the epistle. In this regard, convincing arguments have been presented by Mercati for dating the manuscript at $<1447>$ on the basis of the indication of the month (August) and of the indiction (the tenth). During the middle decades of the fifteenth century the indiction fell in August only in the years 1432, 1447, 1462, 1477: the first date is for obvious reasons impossible since the text mentions the Council of Ferrara-Florence (1437-1439); the last two appear far away in time from the events reported and are therefore not suitable.

42 Not to be confused with the better known Isidoros of Kiev, who had already embraced the cause of the Union of Churches for several years.

43 The text, which is also preserved in manuscript Vatican City, BAV, Vat. gr. 1147 (Dyktion 67778) (sixteenth century; fols $215^{\mathrm{r}}-216^{\mathrm{r}}$ ), has been published and translated into French by Laurent 1959, 198-200. 
already been highlighted earlier. Consider, for example: the ligature of rho with the following letter, traced from the descender stroke (1); the sequence pi-alpharho (2), with an upwards bending of the head-stroke of the minuscule letter pi, letter alpha above the headline and the bow of rho originating from the descender stroke of alpha (the same occurs in the sequence alpha-rho in ligature with the following letter [3]); sigma conjoined with the circumflex accent (4), as already noticed above; the ligature sigma-omega (5), realised by means of a series of left-turning curves leading to the making of two bows for the closed omega; sigma conjoined with iota (6); the sequence tau-rho-iota, made up of the succession of four strokes (7); finally, the ligature iota-omega realised beneath the baseline (8).

Table 2: Makarios of Halicz and Makarios of Serres: two hands or one?

\begin{tabular}{|c|c|c|c|c|c|c|c|c|c|}
\hline & 1. & 2. & 3. & 4. & 5. & 6. & 7. & 8. & \\
\hline $\begin{array}{l}\text { Makarios } \\
\text { of Serres } \\
(P L P \\
16274)\end{array}$ & & 1 & & & & & & & $\begin{array}{l}\text { Vat. gr. } \\
1858\end{array}$ \\
\hline $\begin{array}{l}\text { Makarios } \\
\text { of Halicz } \\
(P L P\end{array}$ & & & & & & & & & $\begin{array}{l}\text { Lond. } \\
\text { Arundel } \\
528\end{array}$ \\
\hline 16192) & & & & & & & & & $\begin{array}{l}\text { Monac. gr } \\
547\end{array}$ \\
\hline
\end{tabular}

6

The palaeographic examination carried out on Vat. gr. 1858 unexpectedly raises the question - not uncommon in the case of Byzantine scholars and copyists of the Renaissance period - whether two different styles and graphic expressions may actually be attributed to a single historical personality. Here are some observations on this topic by David Speranzi:

The gap between the different expressions of the same hand [...] and the difficulty of clearly tracing the boundaries of the variability of a writing are the reasons why works by several scribes of the fifteenth and sixteenth centuries have been assigned to their 
'palaeographic Doppelgänger', who proved later to be lacking in historical consistency. [...] A problem [...] that can be summarised in the question 'two or one?'. ${ }^{44}$

An unintentional conflation of the two figures - which probably originated from the indication by Mercati - had already emerged in a study by Georg Hofmann, in which, about the Greek monk Makarios appointed as bishop of Halicz by Pope Callistus III, is said: 'Es ist bis jetzt kein Beweis dafür gebracht worden, dass Makarios von der katholischen Kirche wieder abgefallen sei'; ${ }^{45}$ the statement made by Hofmann, as is easy to understand, makes sense only if one identifies Makarios of Halicz as a well-known member of the clergy who had already rejected the Union promoted by the Catholic Church, such as Makarios the Metropolitan of Serres.

Provided that the hypothesis of a conflation is right, it might be easier to understand at this point the decision taken by the Roman Curia on the issue of the appointment of a bishop charged with task of safeguarding the concerns of the Eastern-rite Greeks of Galicia: an orthodox monk of some reputation, who had already been a metropolitan and who had in the past - even if only temporarily - embraced the concepts of the Council of Ferrara-Florence, might be in the end the most suitable candidate.

A last, a not insignificant detail pointing to a shared identity between the two Makarioi comes from the manuscript itself which preserves the letter of the Metropolitan of Serres. In fact, some sections of the Vatican codex, which is composed of multiple independent codicological units to be ascribed to different periods, most probably belonged to Isidoros of Kiev, who also transcribed some folios (fols $44^{r}-47^{r}, 49^{r}-50^{r}$ ); ${ }^{46}$ with these sections, in addition to the letter by Makarios, it should also be associated the first sheet, containing the draft of Bessarion's epistle to the sons of Georgios Gemistos Plethon, in the hand of Bessarion himself $\left(\right.$ fol. $\left.1^{\mathrm{rv}}\right) .^{47}$ It is difficult to imagine that the recurrence of these

44 Speranzi 2013, 15-16: 'Proprio la distanza tra le diverse manifestazioni di una stessa mano [...] associata alla difficoltà di tracciare con nettezza i possibili limiti della variabilità di una scrittura, ha fatto sì che diversi scribi dei secoli XV e XVI abbiano visto alcuni dei propri prodotti assegnati a loro "doppi paleografici", rivelatisi poi privi di consistenza storica. [...] Un problema [...] sintetizzabile nell'interrogativo "due o uno?”.

45 Hofmann 1946, 228-229.

46 Within this quire one finds a fair copy of the text Sermo $V$ inter concilium Florentinum, edited by Hofmann and Candal 1971, 81-94; regarding the manuscript's belonging to Isidoros, see Mercati 1936, 36-39.

47 Identification by Mercati 1917. The known hands recognized in the Vatican manuscript are those of Dositheos of Drama $\left(4^{\mathrm{r}}-5^{\mathrm{r}}\right)$, Manuel Kalekas (fols $7^{\mathrm{r}}-8^{\mathrm{r}}$ ), Makarios of Ancyra (fols $28^{\mathrm{r}}-$ $42^{\mathrm{r}}$ ), Gregorios Alyates (fols $60^{\mathrm{r}}-62^{\mathrm{v}}$ ), Georgios Moschos (fols $250^{\mathrm{r}}-257^{\mathrm{v}}$ ); for these attributions 
figures (Isirodos and Bessarion), who are central to the biography of Makarios of Halicz, ${ }^{48}$ in the only manuscript that has preserved the memory of the Metropolitan of Serres is due to a mere coincidence.

Table 3: The manuscripts of Makarios (overview)

\begin{tabular}{lll}
\hline$\#$ & Manuscript & Contents \\
\hline 1. & Vienna, Österreichische Nationalbibliothek, phil. gr. 64, fols 139 $-216^{\mathrm{v}}$ & Aristotle \\
2. & Munich, Bayerische Staatsbibliothek, gr. 547, fols 1r-301 & Proclus \\
3. & London, British Library, Arundel 527, fols $5^{\mathrm{v}}-6^{\mathrm{r}}$ & music \\
4. & London, British Library, Arundel 528, fols $9^{\mathrm{r}}-60^{\mathrm{v}}, 111^{\mathrm{r}}-181^{\mathrm{r}}, 185^{\mathrm{r}}-192^{\mathrm{v}}$ & miscellany \\
5. & Paris, Bibliothèque nationale de France, gr. 1312 & ethics, theology \\
6. & Vatican City, Biblioteca Apostolica Vaticana, Vat. gr. 1858, fols $2^{\mathrm{v}}-3^{\mathrm{r}}$ & miscellany \\
\hline
\end{tabular}

\section{7}

All the data collected so far about Makarios - former metropolitan of Serres (before 1447), later a monk of the Basilian monastery of St Cyprian in Constantinople and then, once he arrived in Italy, a copyist working in the circle of Bessarion before his nomination as bishop of Halicz at the end of the 1450s - match with another namesake personality. We learn from Athanasios Chalkeopulos (a Byzantine scholar from the Cardinal's circle), the author of the Liber Visitationis, that he was accompanied on his journey to the monasteries of southern Italy by a certain Makarios, archimandrite of the Basilian monastery of St Bartholomew of Trigona. ${ }^{49}$ The journey was undertaken at the behest of Pope Callistus III; it began in Rome on 1 October 1457 and ended on 5 April 1458. The purpose of the

see $R G K$ III 182, 413, 401, 145, 111 (with bibliography). The scribe of fol. $6^{\text {rv }}$ is to be identified with the so-called 'Anonymus $\chi-\lambda[=29]$ Harlfinger', who was in contact with Bessarion: see Harlfinger 1971, 419; Harlfinger 1974, 18 (no. 15); Stefec 2014, 197. Other anonymous hands appear in other leaves: fols $63^{\mathrm{r}}-88^{\mathrm{v}} ; 89^{\mathrm{r}}-110^{\mathrm{r}} ; 111^{\mathrm{r}}-202^{\mathrm{v}} ; 203^{\mathrm{r}}-233^{\mathrm{v}} ; 258^{\mathrm{r}}-259^{\mathrm{r}}$ (Otrantine scribe?); $260^{\mathrm{r}}-262^{\mathrm{v}}$. A full digitisation of the manuscript is available at <digi.vatlib.it/>.

48 See above, p. 759-760.

49 It is worth remembering that the ecclesiastical dignity of archimandrite was mostly a title of honour and did not require settlement in the eponymous monastery; for the history of this cloister refer to Falkenhausen 1999. 
mission was to gather information on the history of southern monasticism through the exploration of 78 Basilian monasteries. ${ }^{50}$

The coincidence of characters (again Pope Callistus III and Bessarion), times (the months between the end of 1457 and the beginning of 1458) and places (the city of Rome) is undoubtedly striking. The hypothesis of a shared identity between the one Makarios (first metropolitan of Serres and later bishop of Halicz) and the other, archimandrite of Trigona, may not rely on a mere combination of coincidences. Unfortunately, nothing emerges from the pages of the Liber Visitationis. It will be the task of future investigations to find new evidence that will enable us to give this hypothesis a confirmation.

\section{Abbreviations}

PLP

RGK I-III
Erich Trapp (ed.), Prosopographisches Lexikon der Palaiologenzeit, Vienna: Verlag der Österreichischen Akademie der Wissenschaften, 1976-1996. griechischen Kopisten 800-1600, I: Handschriften aus Bibliotheken Großbritanniens, Vienna: Verlag der Österreichischen Akademie der Wissenschaften, 1981; II: Handschriften aus Bibliotheken Frankreichs und Nachträge zu den Bibliotheken Großbritanniens, Vienna: Verlag der Österreichischen Akademie der Wissenschaften, 1989; III: Handschriften aus Bibliotheken Roms mit dem Vatikan, Vienna: Verlag der Österreichischen Akademie der Wissenschaften, 1997.

\section{References}

Adam, Miroslav (2008), 'Le disposizioni dei Romani Pontefici del periodo medievale rispetto ai cristiani Orientali in Ungheria', Angelicum, 85: 321-340.

Brockmann, Christian, Vito Lorusso and Stefano Martinelli Tempesta (2017), 'Exegetische Paratexte zur Physik des Aristoteles in griechischen Manuskripten aus der Renaissance: Einleitung und Edition', Eikasmòs, 28: 261-298.

50 The results of the enquiry by Makarios and Athanasios reported in the Liber Visitationis were published by Laurent and Guillou 1960 (references to the figure of Makarios are in particular found in the pages XIV-XVI, XXIII-XXIV). According to Piromalli 1996, 63, Athanasios was accompanied on his journey by a certain 'Macario Sergi' (a distortion of the Latin word Servi, 'from Serbia', or of 'Serres'?); however, the source of this information is unfortunately not indicated. 
Bunea, Augustin (1904), lerarchia Românilor din Ardeal şi Ungaria, Blaş: Tip. Seminariulŭ Archidiecesan.

Cleminson, Ralph (ed.) (1988), A Union Catalogue of Cyrillic Manuscripts in British and Irish Collections, London: School of Slavonic and East European Studies, University of London.

Darrouzès, Jean (ed.) (1961), Nicétas Stéthatos. Opuscules et lettres, Paris: Éditions du Cerf.

Diller, Aubrey (1967), 'Three Greek Scribes working for Bessarion: Trivizias, Callistus, Hermonymus', in Italia medioevale e umanistica, 10: 403-410.

Dodds, Eric R. (ed.) (1963), Proclus. The Elements of Theology, $2^{\text {nd }}$ edn, Oxford: Clarendon. Fiaccadori, Gianfranco (ed.) (1994), Bessarione e l'Umanesimo. Catalogo della mostra (Venezia, Biblioteca Nazionale Marciana, 27 aprile - 31 maggio 1994), Naples: Vivarium.

Giacomelli, Ciro and David Speranzi (2019), 'Dispersi e ritrovati. Gli Oracoli caldaici, Marsilio Ficino e Gregorio (iero)monaco', Scripta, 12: 113-142.

Giacomelli, Ciro (2020), 'La Vita Procli di Marino di Neapoli fra Niceforo Gregora e Bessarione. Appunti sul Laur. Plut. 86.3, con osservazioni sulla storia del testo del De Pythagorica secta di Giamblico in età umanistica', Scripta, 18: 283-305.

Grosdidier de Matons, Dominique (2008), 'Traces de deux opérations de couture provisoire dans les manuscrits byzantins', in Basiles Atsalos and Nike Tsironi (eds), Actes du Vle Colloque International de Paléographie Grecque (Drama, 21-27 septembre 2003), Athens: Société Hellénique de Reliure, 369-374.

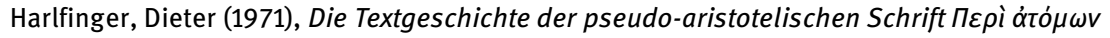
$\gamma \rho \alpha \mu \mu \tilde{\omega} v$, Amsterdam: Hakkert.

Harlfinger, Dieter (1974), Specimina griechischer Kopisten der Renaissance, I, Berlin: Mielke. Harlfinger, Dieter (2011), 'Parekbolaia palaiographika', Parekbolai, 1: 287-296.

Hofmann, Georg (1946), 'Papst Kalixt III. und die Frage der Kircheneinheit im Osten', in Miscellanea G. Mercati, III, Vatican City: Biblioteca Apostolica Vaticana, 209-237.

Hofmann, Georg and Emmanuel Candal (eds) (1971), Isidorus Arch. Kiovensis et totius Russiae. Sermones inter Concilium Florentinum conscripti: e codicibus Graecis autographis deprompti [...], Rome: Pontificium institutum Orientalium Studiorum.

Labowsky, Lotte (1979), Bessarion's Library and the Biblioteca Marciana. Six Early Inventaries, Rome: Edizioni di Storia e Letteratura.

Laurent, Marie-Hyacinthe and André Guillou (1960), Le Liber visitationis d'Athanase Chalkéopoulos (1457-1458). Contribution à l'histoire du monachisme grec en Italie méridionale, Vatican City: Biblioteca Apostolica Vaticana.

Laurent, Vitalien (1959), 'La métropole de Serrès contre le concile de Florence', Revue des Études Byzantines, 17: 195-200.

Martinelli Tempesta, Stefano (2013), 'Per un repertorio dei copisti greci in Ambrosiana', in Federico Gallo (ed.), Miscellanea Graeco-latina, I, Milan: Bulzoni, 101-153.

Martinelli Tempesta, Stefano (2015) 'Trasmissione di testi greci esametrici nella Roma di Niccolò V. Quattro codici di Demetrio Xantopulo e una lettera di Bessarione a Teodoro Gaza', Segno e Testo, 13: 271-350.

Martínez Manzano, Teresa (2013), 'Un copista del lustro bolones de Besarión: el Anonymus Ly, Nea Rhome, 10: 211-243.

Mercati, Giovanni (1917), 'Un autografo del Bessarione', Bessarione, 3: 185-187 [reprinted in Giovanni Mercati, Opere minori, IV, Rome: Biblioteca Apostolica Vaticana, 1937, 22-24].

Mercati, Giovanni (1926), Scritti d'Isidoro il cardinale Ruteno e codici a lui appartenuti che si conservano nella Biblioteca Apostolica Vaticana, Rome: Biblioteca Apostolica Vaticana. 
Mioni, Elpidio (1976), ‘Bessarione scriba e alcuni suoi collaboratori', in Miscellanea marciana di studi bessarionei, Padua: Antenore, 263-318.

Orlandi, Luigi (2015), 'Escerti galenici nella biblioteca di Teodoro Gaza', Studi medievali e umanistici, 13: 267-273.

Orlandi, Luigi (2019a), 'La scrittura greca di Giorgio Amirutze. Una proposta', Rivista di Studi Bizantini e Neoellenici, 56: 1-30.

Orlandi, Luigi (2019b), 'Da Bologna all'Inghilterra: un codice di Leida, Emanuele da Costantinopoli e l'Anonymus Ly Harlfinger', Scriptorium, 73: 281-306.

Orlandi, Luigi (2020a), 'Preistoria di un'edizione mancata: il Macrobio di Gaza e Bussi', Studi medievali e umanistici, 18 (forthcoming).

Orlandi, Luigi (2020b), 'Bessarione e il suo entourage: una postilla sul restauro quattrocentesco del Marc. gr. Z. 454 (= Venetus A)', Nea Rhome, 17: 399-406.

Philippides, Marios and Walter K. Hanak, (2018), Cardinal Isidore, c. 1390-1462. A Late Byzantine Scholar, Warlord, and Prelate, London: Routledge.

Piromalli, Antonio (1996), La letteratura calabrese, I, $3^{\text {rd }}$ edn, Cosenza: Luigi Pellegrini Editore.

Prochaska, Antoni (1923), 'Nieznane dokumenta do unji Florenckiej w Polsce', Ateneum Wileńskie, 1: 67-74.

Rashed, Marwan (2001), Die Überlieferungsgeschichte der aristotelischen Schrift De generatione et corruptione, Wiesbaden.

Saffrey, Henri-Dominique (1965), 'Note autographes du Cardinal Bessarion dans un manuscrit de Munich', Byzantion, 35: 536-563.

Saffrey, Henri-Dominique and Leendert Gerrit Westerink (eds) (1968), Proclus. Théologie platonicienne, I, Paris: Les Belles Lettres.

Saffrey, Henri-Dominique (1979), 'Pie II e les prêtres uniates en Crète au XVe siècle', Thesaurismata, 16: 39-53 [reprinted in Franz Paschke, (ed.), Überlieferungsgeschichtliche Untersuchungen, Berlin: Akademie-Verlag, 1981, 515-524 and in Henri-Dominique Saffrey, L'héritage des anciens aux Moyen Âge et à la Renaissance, Paris: Vrin, 2003, 167-176].

Speranzi, David (2012), “'De’ libri che furono di Teodoro”: una mano, due pratiche e una biblioteca scomparsa', Medioevo e Rinascimento, 26 [= n.s. 23]: 319-354.

Speranzi, David (2013), Marco Musuro. Libri e scrittura, Rome: Accademia dei Lincei.

Speranzi, David (2015), 'Appunti su Alessio Celadeno: anelli, stemmi e mani', in Alessandro Capone (ed.), Circolazione di testi e scambi culturali in Terra d'Otranto tra Tardoantico e Medioevo, Vatican City: Biblioteca Apostolica Vaticana, 199-213.

Speranzi, David 2016, Omero, i cardinali e gli esuli. Copisti greci di un manoscritto di Stoccarda, Madrid: Dykinson.

Speranzi, David (2017), 'Scritture, libri e uomini all'ombra di Bessarione. I. Appunti sulle lettere del Marc. gr. Z. 527 (coll. 679)', Rinascimento, 57: 137-197.

Speranzi, David (2018), 'Scritture, libri e uomini all'ombra di Bessarione. II. La “doppia mano” di Atanasio Calceopulo’, Rinascimento, 58: 193-237.

Stefec, Rudolf S. (2013), 'Zwischen Urkundenpaläographie und Handschriftenforschung: Kopisten am Patriarchat von Konstantinopel im späten 15. und frühen 16. Jahrhundert', Rivista di Studi Bizantini e Neoellenici, 50: 303-326.

Stefec, Rudolf S. (2014), 'Die Handschriften der Sophistenviten Philostrats', Römische historische Mitteilungen, 56: 137-206.

von Falkenhausen, Vera (1999), 'S. Bartolomeo di Trigona: storia di un monastero greco nella Calabria normanno-sveva', Rivista di Studi Bizantini e Neoellenici, 36: 93-116. 


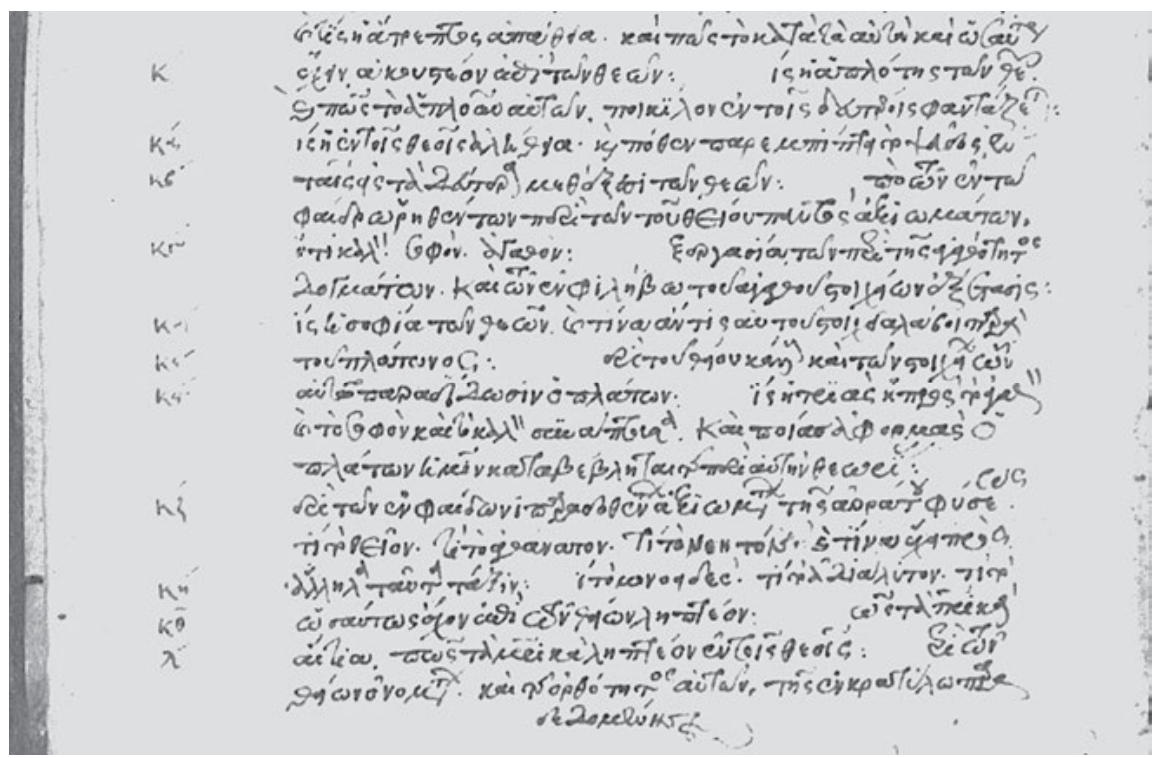

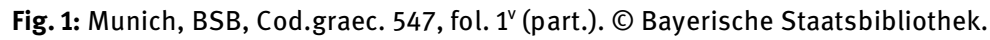

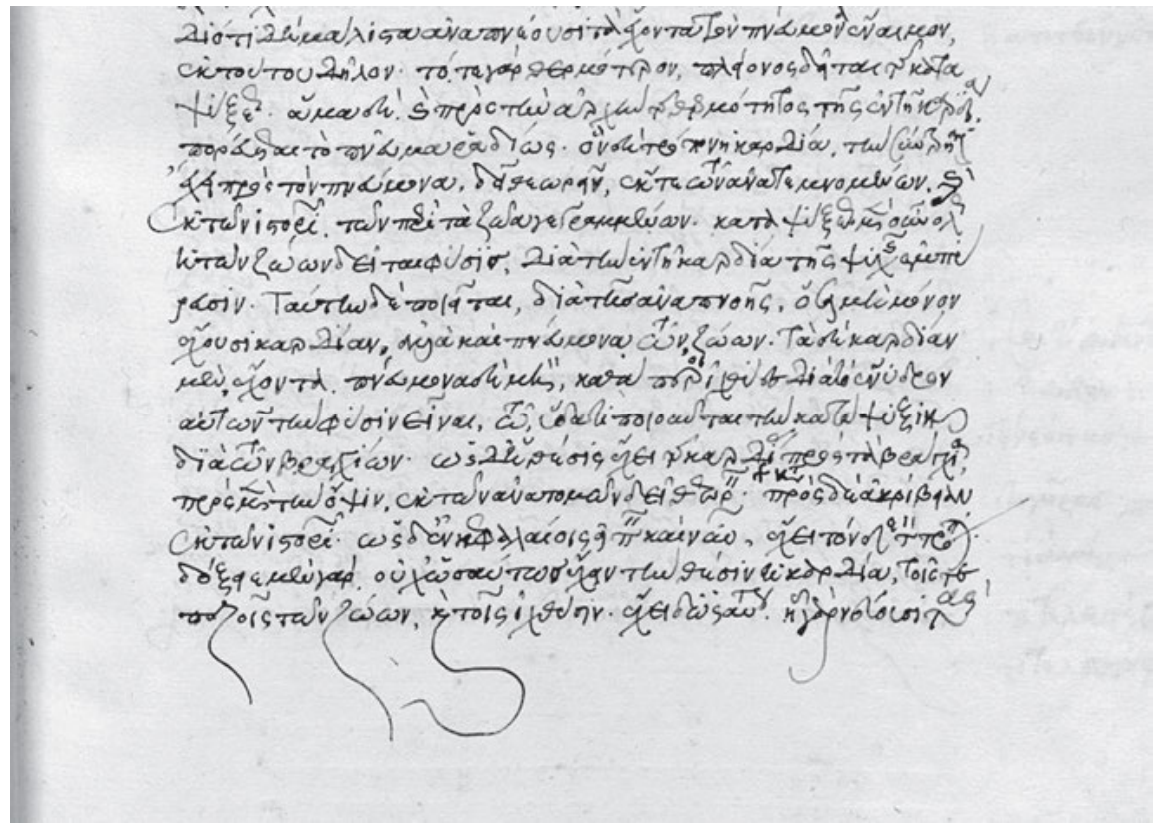

Fig. 2: Vienna, ÖNB, phil. gr. 64, fol. $205^{r}$ (part.). @ Österreichische Nationalbibliothek. 


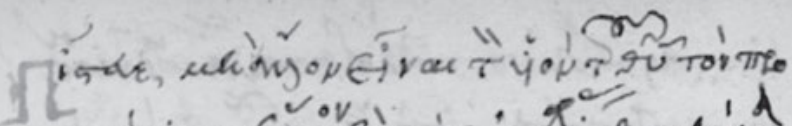

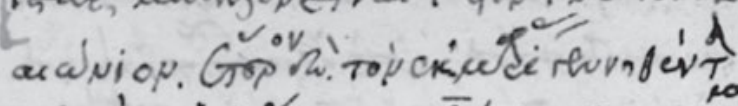

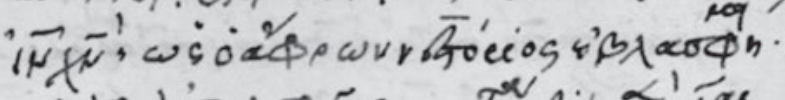

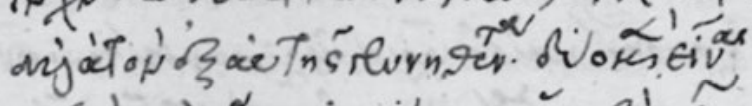

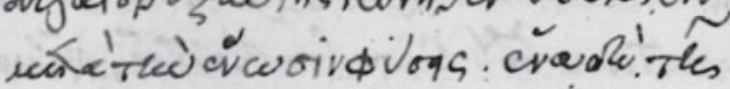

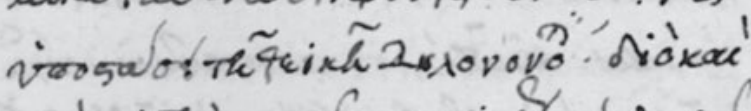

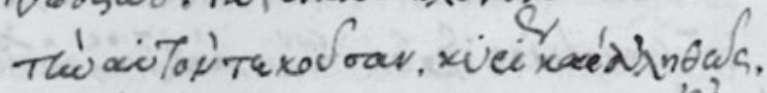
Sxoftivar, xacroyeisotóno karky i 2 . Th o

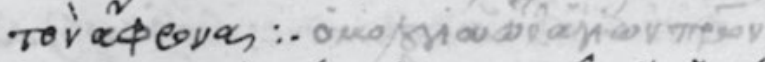

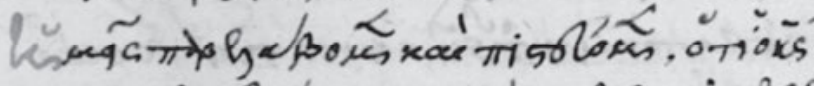

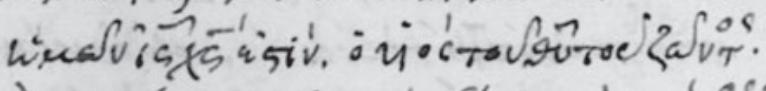
1 or in a i i oste

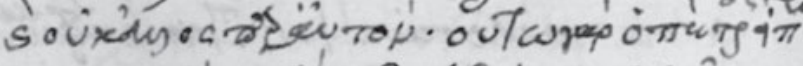

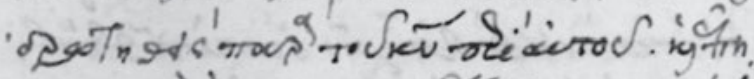

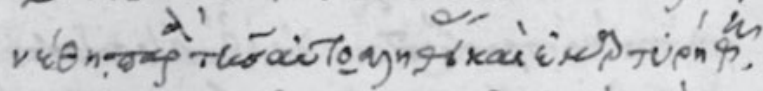

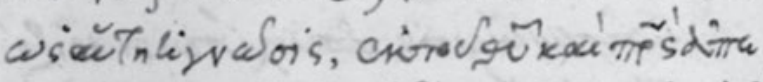

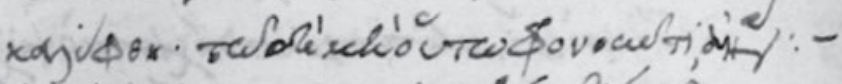

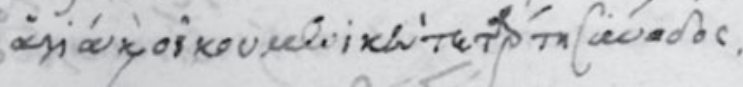

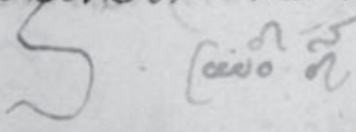

Fig. 3: London, BL, Arundel 528, fol. $113^{r}$. (c) British Library. 


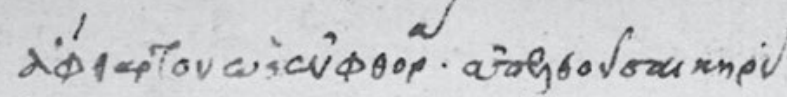

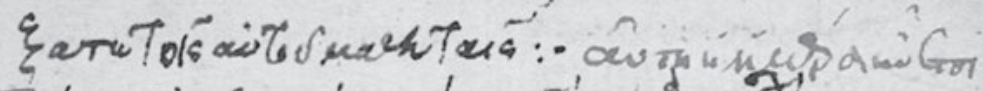

]

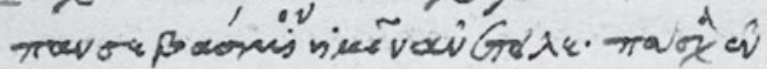
fap aidis

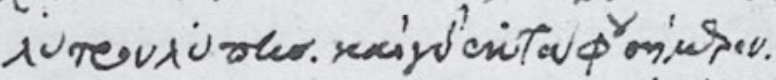

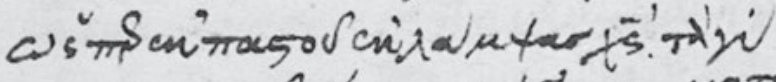

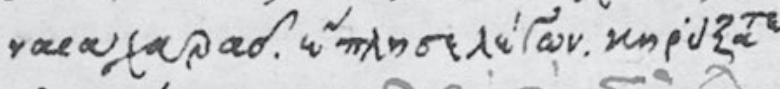

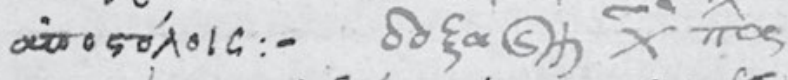

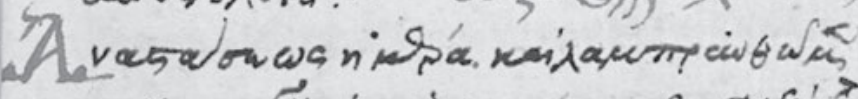

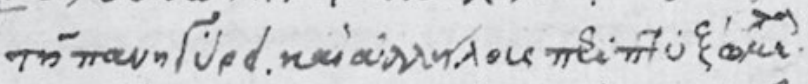

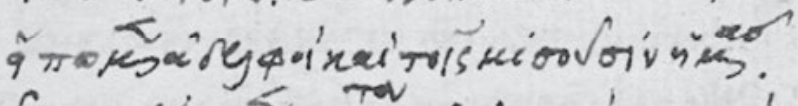

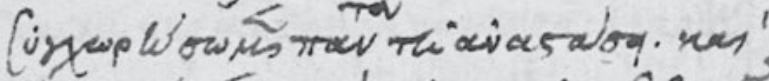

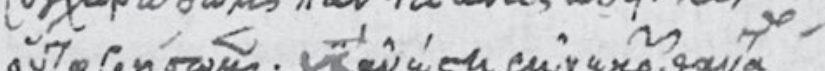

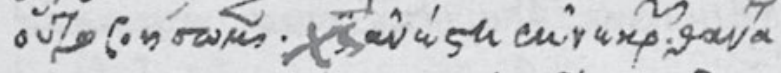

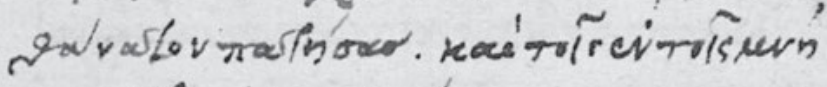

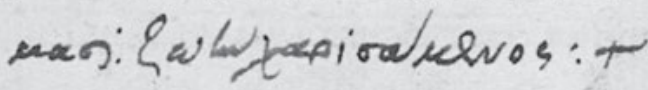

Fig. 4: London, BL, Arundel 527, fol. 6r. (c) British Library. 
Eimplivertaépe orisjléntar ojur:

9

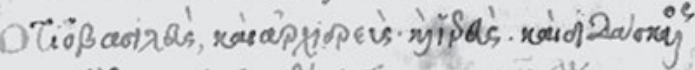

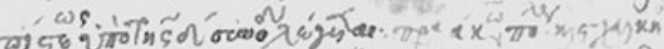

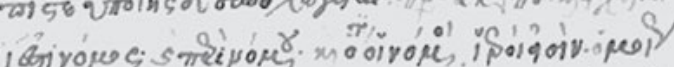

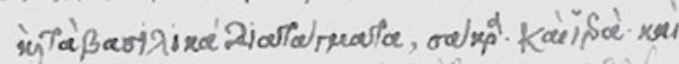

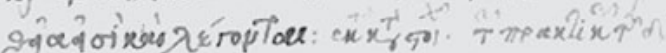

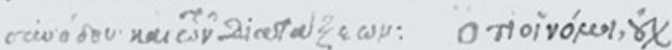

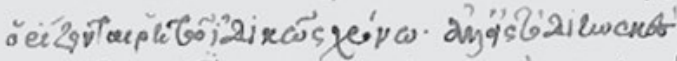

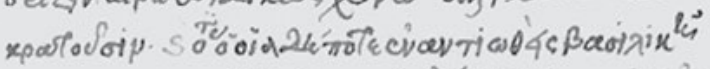

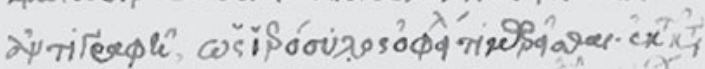
O

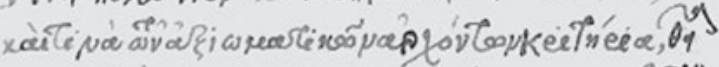

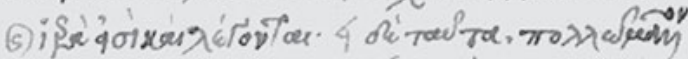

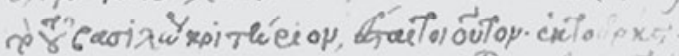

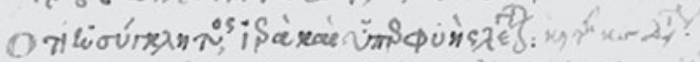

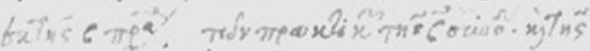

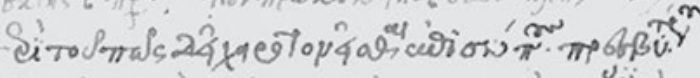

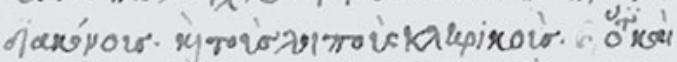

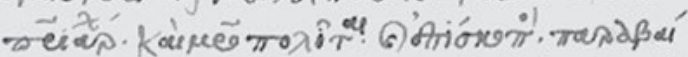

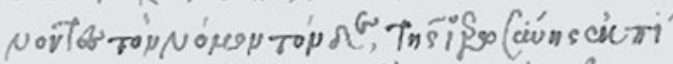

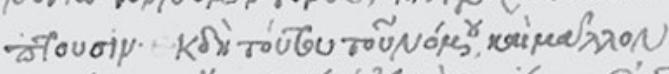

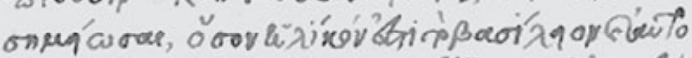

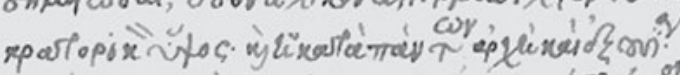

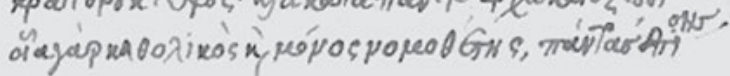


